\title{
Evaluation of Vegetative Growth Parameters of Almond Varieties (Prunus Amygdalus L.) at Holleta, Central Highlands of Ethiopia
}

\author{
Tajebe Mosie Getaneh Seleshi Habtam Setu \\ Ethiopian Institute of Agricultural Research, Holeta Agricultural Research Center, \\ P.O.Box 31, Holeta Ethiopia
}

\begin{abstract}
The study's goal was to evaluate almond cultivars' vegetative growth performance and adaptability under Holetta conditions. The trial was carried out at the Holetta Agricultural Research Center with four almond varieties arranged in RCBD and three times replicated. Ferraduel had the highest tree height of $129.58 \mathrm{~cm}$ in the first growing season of 2011, followed by Desmayo $(108.75 \mathrm{~cm})$, Ferragnes $(96.17 \mathrm{~cm})$, and Marcona $(95.56 \mathrm{~cm})$. The Ferraduel variety has the highest recorded height except in 2014 and 2015. Annual growth differed significantly between years, with 2015 recording the most $(42.7 \mathrm{~cm})$ and 2013 following closely after $(32.8 \mathrm{~cm})$. The crosssectional area of a tree trunk increased in general as the growth season progressed. In 2011, Marcona had the lowest TCSA $\left(2.04 \mathrm{~cm}^{2}\right)$, whereas Ferragnes $\left(86.58 \mathrm{~cm}^{2}\right)$ had a much lower TCSA in 2016 . The exponential canopy stretch was somewhat limited from 2012 to 2013 . The growing season 2016 has the most main branches, followed by the growing season 2013, with the values of 3.44 and 3.14, respectively. While the 2014 growing season had the fewest major branches, followed by the 2015 growing season with values of 2.19 and 2.58, respectively. Across all growing seasons, the Desmayo variety exhibited the highest branching height. With increasing tree height, TCSA and canopy stretch grow linearly. It also shows non-linear positive correlations of 0.43 and 0.35 with yearly growth rate and branching height, respectively.
\end{abstract}

Keywords: almond, variety, year, vegetative, TCSA

DOI: $10.7176 /$ ALST/91-01

Publication date: January $31^{\text {st }} 2022$

\section{Introduction}

Almond (Prunus amygdalus L) and its wild relatives thrive in the subsoil during hot, dry, and chilly summers comparable to those seen in Mediterranean climes (Gradziel, 2009; Kester et al., 1991). Almonds are a small to medium-sized fruit tree of the Rosaceae family and the genus Prunus (Kester et al., 1991). The tree may be fully commercially grown to a height of $10-15 \mathrm{~m}$ and can be produced for 50 years or more, depending on the growing site and conditions (Kester et al., 1996). The leaves are linear to oval in shape, with notched margins (Rieger, 2006).

Successful almond production depends largely on the variety selected by the grower. Species should be carefully chosen to match growing soil conditions and local pest and disease pressure. The production, growing season, and growth habit of different species (or variations) can vary. During sleep, different varieties respond differently to cooler or warmer temperatures. When selecting new orchards, understanding different climates is critical (Covert, 2011). Almonds are not self-sufficient, thus types must be pollinated with other varieties to generate a successful commercial crop. Commercial pollination of almonds is fully dependent on bees for pollination and subsequent nut set success (Thorp, 1996).

The almond tree enters adolescence, or the phase after active growth, after being distributed and established in the orchard. This period is characterized by the growth and development of shoots as the tree matures and fully develops (Faust, 1989b). Alternating low and high temperatures promote plant growth more than steady temperatures. Excellent temperatures, including lower and upper criteria, differ between species and even between individual plants, depending on their specific organs and age (developmental condition of those organs) (Opik and Rolfe, 2005a).

Many temperate plants require cold temperatures to grow normally during dormancy. Growers must comprehend the relationship between variety, cooling requirements, and the climate of a successful production field. If winter temperatures do not exceed the variety's cold requirements, the trees will exhibit delayed germination and leaf acquisition, fruit set and buttoning (flowers that show external signals of excellent pollen but do not develop into fruit), and declining fruit quality (Byrne and Bacon, 1992).

The Ethiopian highlands are endowed with a mosaic of soil and climate conditions conducive to the production of temperate fruits and nuts. It is distinguished by different topography and agro-ecological zones, with over half of the total area being highland with elevations ranging from 2000 to $4500 \mathrm{~m}$ a.s.l, ample water supplies, and low winter temperatures that can support the growth of several temperate fruit crops (Dereje et al., 2010). Temperate fruits were first introduced for research purposes in the 1970s (Godfrey and Bereke-Tsehay, 1987). Following this, In 2011, four almond varieties were introduced to Ethiopia and established at the Holetta Agricultural Research Center to study their adaptability. As a result, the study's objective was to assess the 
vegetative growth performance and adaptability of almond cultivars.

\section{Materials and methods Experimental site description}

The research was carried out at the Holeta Agricultural Research Center (HARC), which is located at an elevation of $2400 \mathrm{~m}$ a.s.1., at $\mathrm{N} 9^{\circ} 3^{\prime}$ and $\mathrm{E} 38^{\circ} 2^{\prime}$ '. The area has a mean annual rainfall of $1041.4 \mathrm{~mm}$ and relative humidity of 58.7 percent. The major rainy season lasts from June to September, accounting for $70 \%$ of the total rainfall, with the remaining 30\% falling between February and April. The average annual maximum and lowest temperatures are $21.7^{\circ} \mathrm{C}$ and $6.7^{\circ} \mathrm{C}$, respectively (EIAR, 2017). The soil type in the area is primarily Nitosol, which has an average organic matter content of 1.8 percent, a nitrogen content of $0.17 \%$, a phosphorus content of $4.55 \mathrm{ppm}$, the potassium content of $1.12 \mathrm{Meq} / 100 \mathrm{~g}$ of soil, and a $\mathrm{pH}$ of 5.24 (Gemechu, 2007).

\section{Methodology and field management}

In 2011, four almond cultivars were brought from Spain and established at the Holeta Agricultural Research Center: Marcona, Desmayo, Ferragnes, and Ferraduel. The experiment was set up with three replications in a completely randomized block design (RCBD). Four plants were planted in each plot, with a $4 \mathrm{~m} \mathrm{x} 4 \mathrm{~m}$ spacing between plants and rows. All necessary field management procedures were carried out, including manure and fertilizer application, irrigation water supply, pruning and training, weeding, and pest and disease control.

\section{Data collection}

Every year, data for growth metrics were collected for each variety at the commencement of the dormancy break (September-October).Among them;

Tree height (cm): was taken by measuring the height of the tallest branch from the ground using height meter. Annual shoot growth (cm): was determined by measuring the lengths of one season-grown bud stick from the North, South, East, and West directions, and the average length of four bud sticks was used for this study.

Tree trunk cross-sectional area (TCSA) $\left(\mathbf{c m}^{2}\right)$ : The tree trunk diameter was measured $10 \mathrm{~cm}$ above the graft union to calculate TCSA using the equation (Westwood et al., 1963).

$\operatorname{TCSA}\left(\mathrm{cm}^{2}\right)=\frac{\pi D^{2}}{4}$

Where, $\pi=3.14$, $\mathrm{D}$ is the diameter measured $10 \mathrm{~cm}$ above the graft union.

Canopy stretch (width) (m): was the mean measurement of the spreading of branches from North to South and from East to West directions and calculated as follows (Liu et al., 2021).

Canopy stretch $($ width $)=\frac{D N S+D E W}{2}$

Where DNS is the North-South width and DEW is the East-West width.

Number of main branches: was the number of primary branches arose from the main stem.

Branching height (cm): was measured from ground level to the point of the first main scaffold branch emerged.

\section{Data analysis}

The parameters were subjected to an analysis of variance (ANOVA) using SAS 9.3 statistical software, and treatment means were computed using the Least Significant Difference Test at a 5\% probability level (Gomez and Gomez, 1984).

\section{Result and discussion \\ Tree height}

The interaction of variety and year produced a highly significant change in tree height $(P \leq 0.0001)($ Table 1$)$. There is also a noticeable difference between kinds and years. Ferraduel had the tallest tree height of $129.58 \mathrm{~cm}$ in the first growing season of 2011, followed by Desmayo $(108.75 \mathrm{~cm})$, Ferragnes $(96.17 \mathrm{~cm})$, and Marcona $(95.56$ $\mathrm{cm})$. With the exception of 2014 and 2015, the Ferraduel variety had the maximum recorded height. Even if the longest tree height does not differ significantly between 2014 and 2015, the Ferraduel variety's limited growth may be attributed to tree pruning in 2013. Except for 2015, there is no statistically significant difference in pruning between cultivars Ferraduel and Desmayo, and the same is true for Marcona and Ferragnes. With the exception of 2012 and 2013 (with values of $186.5 \mathrm{~cm}$ and $189.9 \mathrm{~cm}$, respectively), statistically significant differences in variable years were noted. The record for the greatest height was set in 2016 with a measurement of $460.7 \mathrm{~cm}$. In all species, the size of the tree determined reproductive performance. Larger trees were more capable of acquiring and storing minerals and carbohydrates, and they produced more fruit (Carbone et al., 2013). The highest value of growth parameters discovered in plants from early planting may be connected to higher temperatures that prevail during the growth phase, hastening plant vegetative growth (Rahman et al., 2014). 


\section{Annual shoot growth}

The annual growth rate of almond varieties combined with the growing season showed a highly significant difference $(P \leq 0.0001)$ (Table 1$)$. The length of new bud sticks was not taken in the first two growing seasons (2011 and 2012) since there was no clear delimit for one season growth and no significant difference between them. However, there was a large disparity between years, with $2015(42.7 \mathrm{~cm})$ being the highest and 2013 being the lowest $(32.8 \mathrm{~cm})$. Changes in environmental circumstances (temperature) and field management could be to cause (irrigation and cultivation). Except for Ferraduel, which has the highest yearly growth rate of $21.8 \mathrm{~cm}$, there is no statistically significant difference amongst varieties. For a long time, heavy or severe pruning was thought to promote vigorous vegetative growth over flower bud development (Marshall, 1931). According to Paul et al. (2017), the vegetative development changed depending on the environmental conditions.

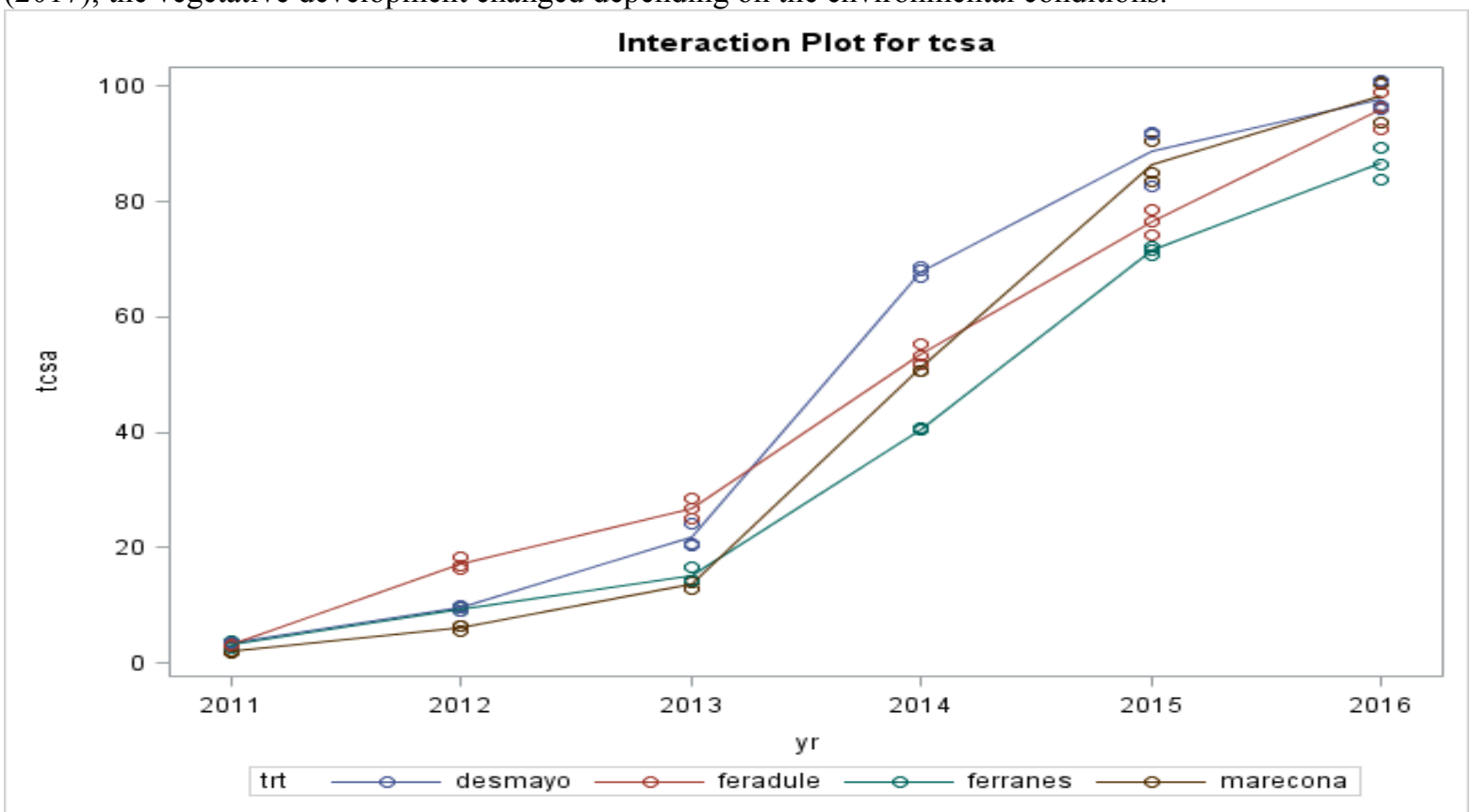

Figure 1. Interaction plot for variety and year for dependent variable trunk cross-sectional area (TCSA)

\section{Tree trunk cross-sectional area}

The interaction effect of variety and year indicated a highly significant difference $(P \leq 0.0001)$ in tree trunk crosssectional area (fig 1). The cross sectional area of a tree trunk expanded in general as the growth season progressed. In 2011, Marcona had the lowest TCSA $\left(2.04 \mathrm{~cm}^{2}\right)$, but Ferragnes have had a much lower TCSA $\left(86.58 \mathrm{~cm}^{2}\right)$ in 2016 (Figure 1). TCSA showed an exponential trend throughout growing seasons for all varieties (Figure 1). The most frequent measurement of a tree's size and, consequently, its fruit-bearing capacity is the trunk cross sectional area (Wright et al., 2006). The width of a tree trunk's trunk is an important indicator of its strength. The widening of the trunk could be owing to the root system's high absorption, which aids in the production of organisms to expand the crown, which, in turn, aids in the formation of many xylem and phloem elements (Kiprijanovski et al., 2009). TCSA and the number of fruits per plant were influenced by both the training strategy and the rootstock. 


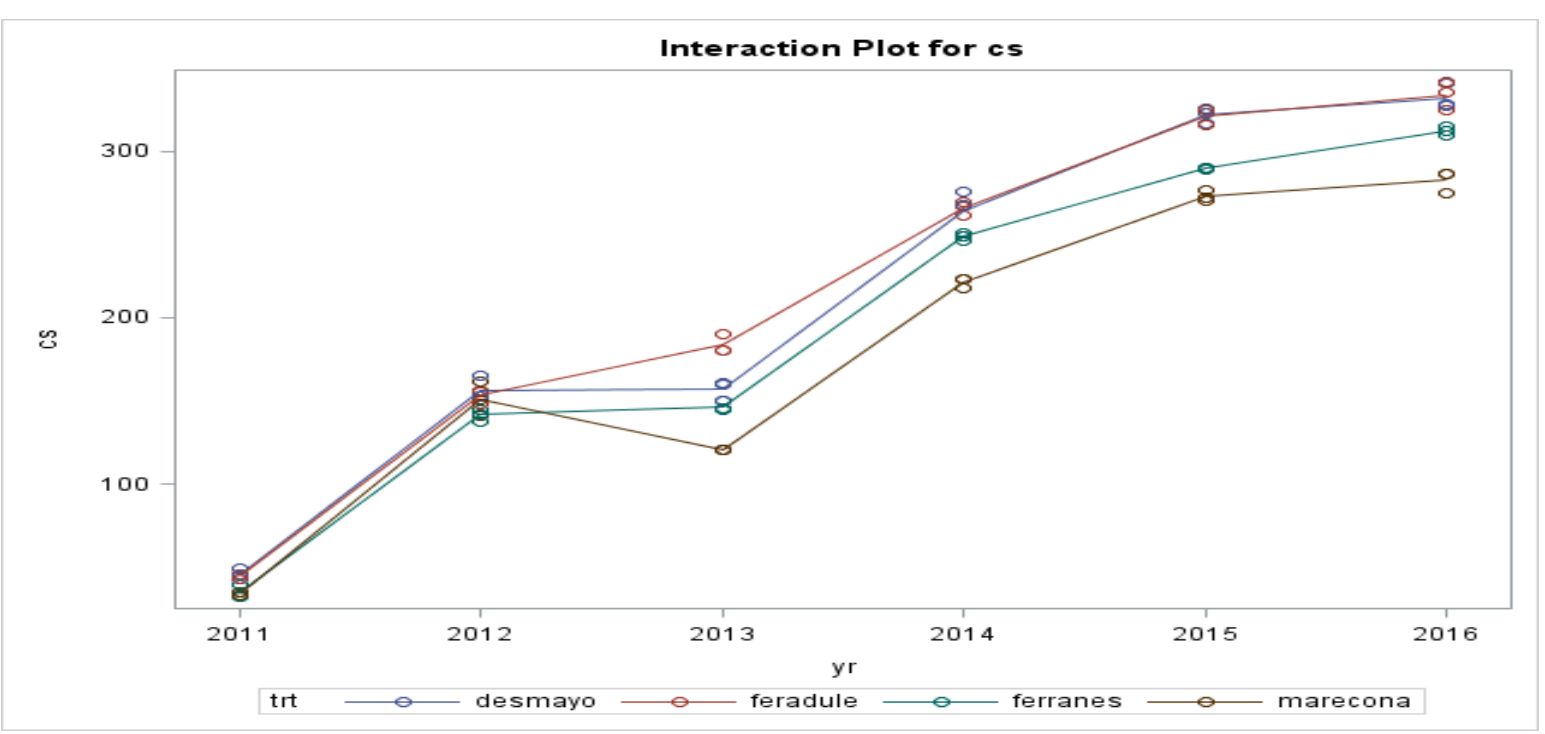

Figure 2. Interaction plot for variety and year for dependent variable canopy stretch

\section{Canopy stretch (m)}

On canopy stretch, the combined effect of variety and year is highly significant $(P \leq 0.0001)$ (fig 2$)$. In the first year of planting, there was no significant difference between the varieties Marcona $(34.38 \mathrm{~cm})$ and Ferragnes $(35.00 \mathrm{~cm})$, and the same is true for Ferraduel $(45.21 \mathrm{~cm})$ and Desmayo $(46.25 \mathrm{~cm})$. The exponential canopy stretch was somewhat limited from 2012 to 2013 (Figure 2). This could be owing to growth restrictions imposed by the environment. Plant growth is influenced by the origin of the planting materials (Yudohartono and Ismail, 2013). The canopy pattern varies from plant to plant and can be categorized into several groups. Large trees are more productive than trees with smaller diameters, according to Molina et al. (2011). Fruit yield is determined by the volume of the crown rather than the width of the stem, with larger trees producing more fruit. Weather conditions, as well as the volume of the tree crown, are important factors in fruit production. Differences in canopy spread could be caused by environmental factors such moisture content and soil temperature, as well as soil and disease factors that affect plant emergence and survival (Nigam, 1992).

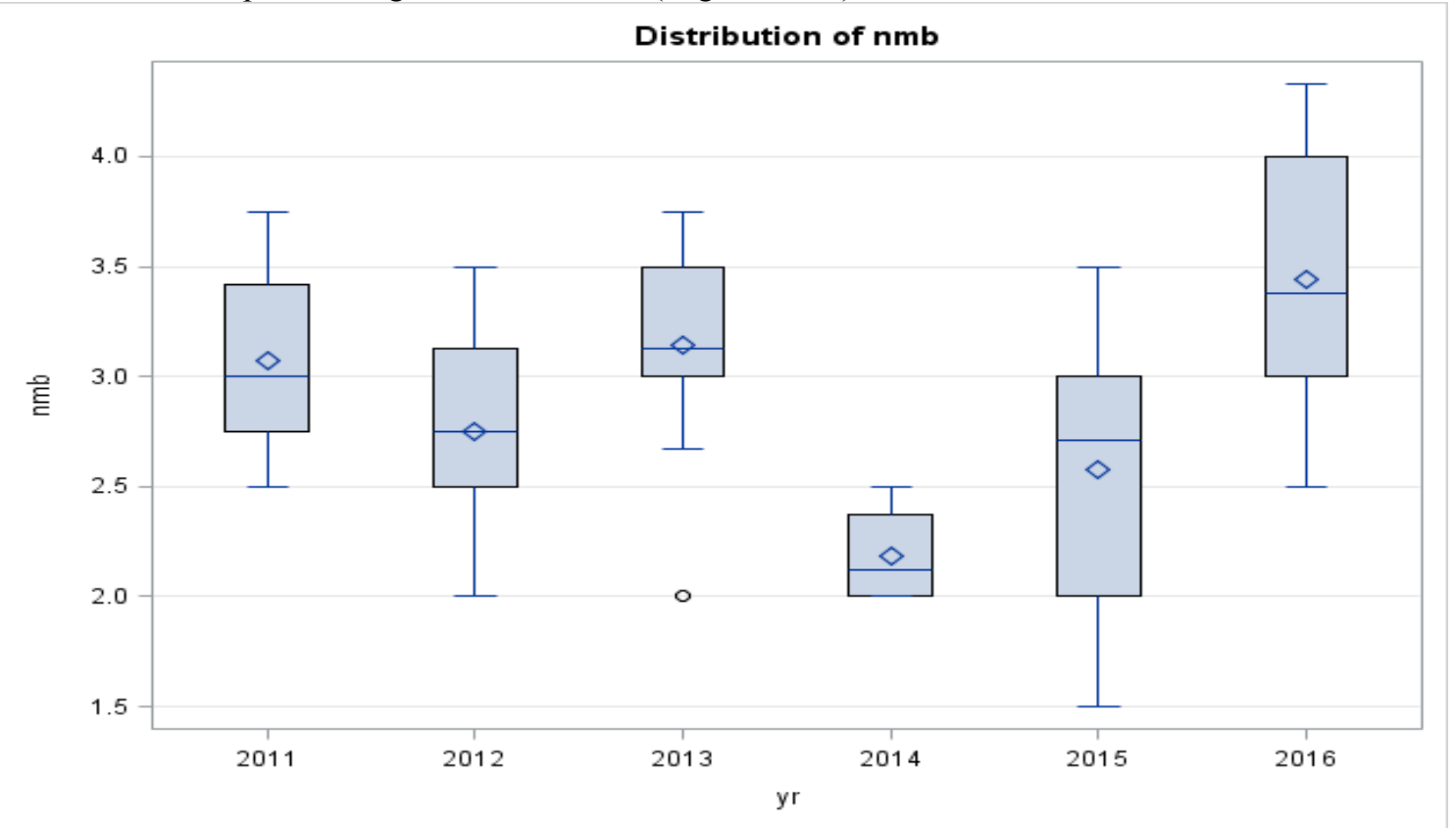

Figure 3. Distribution of number of main branches across years

\section{Number of main branches}

The number of main branches is unaffected by the combined effect of variety and year $(P \leq 0.05)$ (Table 1$)$. However, the effects of year and variety separately (Figure 3 and 4$)$ show a highly significant difference $(P \leq$ 0.0001). The planting season 2016 has by far the most major branches, followed by the growth season 2013 with 
values of 3.44 and 3.14, respectively. Pruning in 2013 may be to cause for the low number of major branches (Figure 3). The Feraduel variety had the most main branches, followed by Marcona and Desmayo, with values of $3.21,2.92$, and 2.83, respectively. Although the branches are not the plant's direct reproductive structures (i.e., they do not photosynthesize), they are important because they allow the leaves to spread out in space, letting water and nutrients flow from the soil to the leaves easier (Paoletti et al., 2021). Unit leaf biomass, as well as large branching, ensure that the greatest branches are sustained by the same stem, and other secondary branches are supported by each branch head, and so on, up to the shoots, which are producers empowered to achieve more diversity in reproductive structures (Rosati et al., 2013).

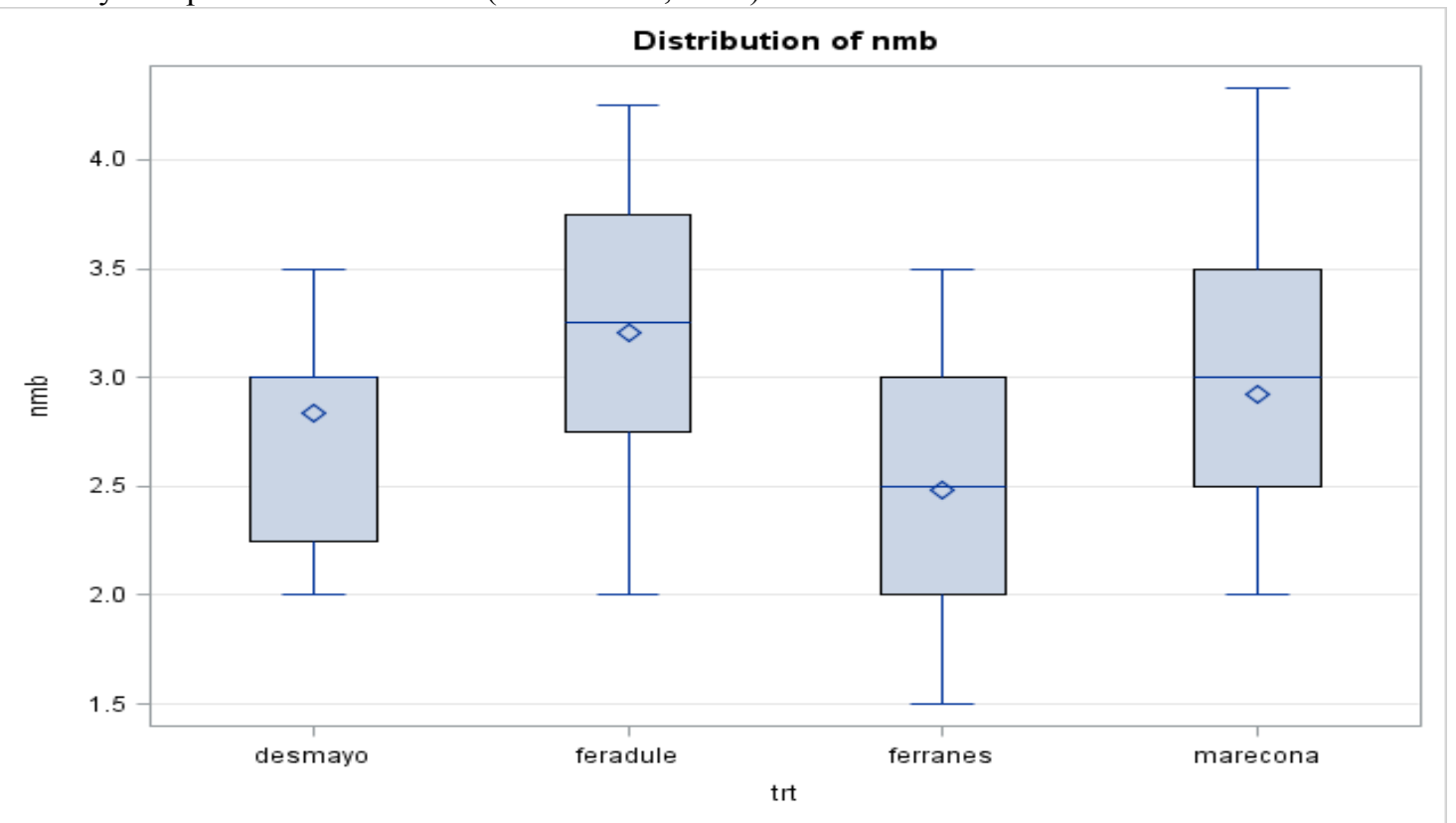

Figure 4. Distribution of number of main branches for varieties

\section{Branching height $(\mathrm{cm})$}

There was a highly significant difference in branching height $(\mathrm{P} \leq 0.0001)$ for the interaction impact of year and variety (Table 1). Even though it was not statistically different from Ferraduel (46.58), Desmayo (48.67) had the highest branching height in the first growing season of 2011. Throughout all growth seasons, the Desmayo cultivar has the highest branching height. In 2013, the branching height of Marecona and Ferragnes types decreased, probably as a result of pruning, which encourages new scaffold branch growth. By enhancing cytokinin transfer from rootstock to scion, grafting height can influence branching height and stimulate lateral bud growth (Karlidag and Esitken, 2012). The number of lateral branches has a big influence on the tree's optimal structure. Furthermore, fruit tree fertility and fruit development are influenced by the height, orientation, and angle of lateral branches with the stem (Yldrm and Kankaya, 2004). 
Table 1. Impact of growing season and variety on vegetative growth parameters of almond (means $\pm \mathrm{sd}$ )

\begin{tabular}{|c|c|c|c|c|}
\hline \multirow[t]{2}{*}{ Year } & \multirow[t]{2}{*}{ Variety } & \multicolumn{3}{|c|}{ Growth parameters } \\
\hline & & Tree height $(\mathrm{cm})$ & New growth $(\mathrm{cm})$ & Branching height $(\mathrm{cm})$ \\
\hline 2011 & Marcona & $95.56 \mathrm{~b} \pm 1.0$ & $0.00 \mathrm{a} \pm 0.0$ & $32.25 \mathrm{~b} \pm 1.1$ \\
\hline 2011 & Ferragnes & $96.17 \mathrm{~b} \pm 3.8$ & $0.00 \mathrm{a} \pm 0.0$ & $36.67 \mathrm{~b} \pm 1.4$ \\
\hline 2011 & Desmayo & $108.75 b \pm 7.6$ & $0.00 \mathrm{a} \pm 0.0$ & $48.67 \mathrm{a} \pm 4.4$ \\
\hline 2011 & Ferraduel & $129.58 \mathrm{a} \pm 12.6$ & $0.00 \mathrm{a} \pm 0.0$ & $46.58 \mathrm{a} \pm 0.4$ \\
\hline 2012 & Marcona & $135.00 \mathrm{c} \pm 5.2$ & $0.00 \mathrm{a} \pm 0.0$ & $73.17 \mathrm{~b} \pm 0.3$ \\
\hline 2012 & Ferragnes & $204.72 \mathrm{a} \pm 20.3$ & $0.00 \mathrm{a} \pm 0.0$ & $55.00 \mathrm{~d} \pm 0.0$ \\
\hline 2012 & Desmayo & $175.83 b \pm 18.1$ & $0.00 \mathrm{a} \pm 0.0$ & $84.44 \mathrm{a} \pm 0.9$ \\
\hline 2012 & Ferraduel & $230.42 \mathrm{a} \pm 11.3$ & $0.00 \mathrm{a} \pm 0.0$ & $71.67 \mathrm{c} \pm 0.9$ \\
\hline 2013 & Marcona & $167.67 \mathrm{c} \pm 11.5$ & $23.11 \mathrm{c} \pm 2.2$ & $52.83 \mathrm{c} \pm 4.1$ \\
\hline 2013 & Ferragnes & $182.83 b c \pm 11.9$ & $27.78 \mathrm{c} \pm 2.7$ & $63.50 \mathrm{~b} \pm 5.4$ \\
\hline 2013 & Desmayo & $194.33 b \pm 2.3$ & $34.25 b \pm 3.9$ & $83.11 \mathrm{a} \pm 3.8$ \\
\hline 2013 & Ferraduel & $214.75 a \pm 5.4$ & $46.19 a \pm 2.4$ & $75.50 \mathrm{a} \pm 3.2$ \\
\hline 2014 & Marcona & $247.34 \mathrm{~b} \pm 10.2$ & $31.22 \mathrm{a} \pm 1.2$ & $76.50 \mathrm{~b} \pm 1.3$ \\
\hline 2014 & Ferragnes & $260.60 \mathrm{~b} \pm 9.5$ & $23.10 \mathrm{c} \pm 1.9$ & $59.33 c \pm 3.3$ \\
\hline 2014 & Desmayo & $300.33 a \pm 2.7$ & $26.70 \mathrm{~b} \pm 0.8$ & $85.55 \mathrm{a} \pm 2.2$ \\
\hline 2014 & Ferraduel & $299.54 \mathrm{a} \pm 5.2$ & $31.68 \mathrm{a} \pm 2.5$ & $72.83 b \pm 1.6$ \\
\hline 2015 & Marcona & $384.76 b \pm 4.6$ & $40.07 \mathrm{~b} \pm 1.0$ & $69.67 \mathrm{~b} \pm 0.7$ \\
\hline 2015 & Ferragnes & $363.55 \mathrm{c} \pm 14.2$ & $48.83 \mathrm{a} \pm 4.7$ & $52.93 \mathrm{c} \pm 2.2$ \\
\hline 2015 & Desmayo & $423.27 \mathrm{a} \pm 2.7$ & $39.94 b \pm 0.9$ & $79.00 \mathrm{a} \pm 0.9$ \\
\hline 2015 & Ferraduel & $419.03 a \pm 11.6$ & $41.94 b \pm 2.5$ & $69.25 \mathrm{~b} \pm 0.8$ \\
\hline 2016 & Marcona & $443.79 b \pm 14.4$ & $14.06 \mathrm{a} \pm 0.9$ & $65.06 \mathrm{~b} \pm 2.6$ \\
\hline 2016 & Ferragnes & $439.01 b \pm 20.4$ & $12.04 \mathrm{ab} \pm 0.9$ & $50.28 \mathrm{c} \pm 6.5$ \\
\hline 2016 & Desmayo & $478.18 \mathrm{a} \pm 15.3$ & $12.53 \mathrm{ab} \pm 1.3$ & $72.83 a \pm 2.7$ \\
\hline 2016 & Ferraduel & $481.79 a \pm 16.8$ & $10.78 b \pm 1.6$ & $68.33 \mathrm{ab} \pm 3.3$ \\
\hline & $C V(\%)$ & 4.26 & 9.56 & 4.38 \\
\hline & $L S D$ & 7.70 & 1.24 & 1.89 \\
\hline & gnificance level & $* * *$ & $* * *$ & $* * *$ \\
\hline
\end{tabular}

\section{Correlation between parameters}

As demonstrated in Table 2, tree height exhibited a high positive linear correlation with trunk cross-sectional area $(0.97 \sim 1)$ and canopy stretch $(0.95 \sim 1)$. This indicates that as tree height increases, TCSA and canopy stretch increase with it. It also displays non-linear positive correlations of 0.43 and 0.35 with yearly growth rate and branching height, respectively. Annual growth rate had a positive correlation with TCSA, canopy stretch, and branching height, with values of $0.48,0.56$, and 0.41 , respectively. The number of primary branches was negatively correlated with all other characteristics except height and TCSA. However, the number of main branches has a correlation value of $\sim 0$, indicating that there is no linear link between the variables.

The highly significant positive relationship between desirable traits will help a plant breeder because it may aid in the simultaneous enhancement of both characters (Shiva et al., 2017). In vegetative growth, plant height, canopy volume, and intermodal length were all positively correlated (Shiva et al., 2017). According to the findings Pandey et al., (2007), there were also significant positive associations between vegetative characteristics and yield. Table 2. Pearson correlation coefficient (r) among growth parameters for the adaptation of almond varieties at Holeta

\begin{tabular}{lllllll}
\hline & Height & $\begin{array}{l}\text { Annual } \\
\text { growth rate }\end{array}$ & $\begin{array}{l}\text { Trunk cross } \\
\text { sectional area }\end{array}$ & $\begin{array}{l}\text { Number of } \\
\text { main branch }\end{array}$ & $\begin{array}{l}\text { Canopy } \\
\text { stretch }\end{array}$ & $\begin{array}{l}\text { Branching } \\
\text { height }\end{array}$ \\
\hline Height & 1.00 & & & & & \\
Annual growth rate & $0.43^{* *}$ & 1.00 & & & & \\
Trunk cross sectional area & $0.97 * * *$ & $0.48^{* * *}$ & 1.00 & & & \\
Number of main branch & 0.10 & -0.22 & 0.05 & 1.00 & & \\
Canopy stretch & $0.95 * * *$ & $0.56 * * *$ & $0.93 * * *$ & -0.08 & 1.00 & \\
Branching height & $0.35^{*}$ & $0.41 * *$ & $0.34 * *$ & -0.09 & $0.51 * * *$ & 1.00 \\
\hline
\end{tabular}

$* * *, * *, *, \mathrm{~ns}=$ Correlation is significant at the $0.1 \%, 1 \%$ and $5 \%$ level, respectively

\section{Conclusions}

All vegetative growth parameters are affected by year and variety interaction, with the exception of the number of main branches. Tree height, trunk cross sectional area, and canopy stretch all showed an exponential graph as the 
growth season progressed. However, because field management (mainly pruning) has a direct impact on them, the annual growth rate, number of main branches, and branching height were displayed in a zigzag pattern.

\section{Acknowledgment}

The authors would like to express their gratitude to the researchers who introduced and maintained almond varieties. Field workers and technical assistants also made substantial contributions. Finally, we'd like to thank the Ethiopian Institute of Agricultural Research for their financial assistance.

\section{References}

Paoletti, A., Adolfo, R. and Franco, F. 2021. Effects of cultivar, fruit presence and tree age on whole-plant dry matter partitioning in young olive trees. Heliyon, (7)5:2405-8440.

Byrne, D. H., and Bacon, T. 1992. Chilling estimation: its importance and estimation. The Texas Horticulturist, $18(8), 5,8-9$.

Carbone, M. S., Czimczik, C. I., Keenan, T. F., Murakami, P. F., Pederson, N., Schaberg, P. G. and Richardson, A. D. 2013. Age, allocation and availability of nonstructural carbon in mature red maple trees. The New Phytologist, 200, 1145-1155.

Covert, M.M.2011. The Influence of Chilling and Heat Accumulation on Bloom Timing, Bloom Length and Crop Yield in Almonds (Prunus Dulcis (Mill.)). A Thesis presented to the Faculty of California Polytechnic State University.

Dereje Ashebir, T. Deckers, J. Nyssen, W. Bihon, A. Tsegay, H. Tekie, J. Poesen, M. Haile, F. Wondumagegneheu, and D. Raes, 2010.Growing apple (Malus domestica) under tropical mountain climate conditions in Northern Ethiopia, Experimental Agriculture, vol. 46, pp. 53-65. Available at: https://doi.org/10.1017/s0014479709990470.

EIAR (Ethiopian Institute of Agricultural Research).2017.Holeta Agricultural Research Center Progress Report.

Faust, M. 1989b. Physiology of Temperate Zone Fruit Trees. New York: John Wiley \& Sons.

Gemechu Keneni.2007. Phenotypic diversity for biological nitrogen fixation in Abyssinian field pea (piston sativum var. abyssinicum) germplasm accession. Doctoral Dissertation, Addis AbabaUniversity, Addis Ababa, Ethiopia.

Godfrey-Sam-Aggery W and Bereke-Tsehai Tuku. 1987. Review of deciduous fruits research in Ethiopia and proposal for future research and development direction. First Ethiopian Horticultural Workshop, 20-22 Feb. 1985, Addis Ababa, Ethiopia. Pp. 39-51.

Gomez, A.K. and Gomez, A.A. 1984. Statistical Procedures for Agricultural Research (2nd Edn.). An Inter. Research Institute Book, John Willey and Sons Inc., New York.

Gradziel, T. M. 2009. Almond (Prunus dulcis) Breeding. In S. M. Jain \& P. M. Priyadarshan (Eds.), Breeding Plantation Tree Crops: Temperate Species. New York: Springer. pp. 5-11.

Karlidag, H., Esitken, A. 2012. Effects of grafting height of 'MM106' rootstock on growth, lateral shoot formation and yield in apple trees. J. Hortic. Sci. Biotech. 87, 40 9-412.

Kester, D. E., Gradziel, T. M., and Grasselly, C. 1991. Almonds (Prunus). Paper presented at the Genetic Resources of Temperate Fruit and Nut Crops, The Netherlands.

Kester, D. E., Martin, G. C., and Labavitch, J. M. 1996. Growth and Development. In W. C. Micke (Ed.), Almond Production Manual; pp. 90-97: UC ANR.

Kiprijanovski, M., Ristevski, B., Arsov, T. and Gjamovski, V. 2009. Influence of Planting Distance to the Vegetative Growth and Bearing of 'Jonagold' Apple Cultivar on 'Mm106' Rootstock. Acta Hortic. 825, 453458.

Liu, Xiangyang, Yaxiong Wang, Feng Kang, Yang Yue, and Yongjun Zheng. 2021. Canopy Parameter Estimation of Citrus grandis var. Longanyou Based on LiDAR 3D Point Clouds. Remote Sensing 13, no. 9: 1859. https://doi.org/10.3390/rs13091859

Marshall, R.E. 1931. The fruiting habit of the peach as influenced by pruning practice.

Molina, M., Pardo-De-Santayana M., Aceituno, L., Morales, R. and Tardío, J. 2011. Fruit production of strawberry tree (Arbutus unedo L.) in two Spanish forests. Forestry 84(4):419-429.

Nigam, S. N. 1992. Groundnut: A global perspective. Proceedings of an International Workshop, 25-29 Nov 1991 , ICRISAT Center. Patancheru, Andhra Pradesh, India: ICRISAT.

Opik, H., and Rolfe, S. 2005a. The Physiology of Flowering Plants (4th ed.). Cambridge: University Press.

Pandey, D., Shukla, S.K., Yadav, R.C. and Nagar, A.K. 2007. Promising Guava (Psidium Guajava L.) Cultivars for North Indian Conditions. Acta Hortic. 735, 91-94

Paul, C., Gomasta, J. and Hossain, M.M., 2017. Effects of planting dates and variety on growth and yield of strawberry. International journal of Horticulture, Agriculture and Food science, 1(4), pp.1-12.

Rahman, M.M., M.M. Hossain, Q.A. Khaliq and M. Moniruzzaman, 2014.Effect of planting time and genotypes on growth, yield and quality of strawberry (Fragaria x ananassa Duch.).ScientiaHorticulturae, 167, 56-62. 
Rieger, M. 2006. Introduction to fruit crops: Psychology Press.

Rosati, A., Paoletti, A., Caporali, S. and Perri, E. 2013. The role of tree architecture in super high density olive orchards. Scientia Horticulturae. 161. 24-29.

Shiva, B., Nagaraja, A., Srivastav, M., Goswami, A.K. 2017. Correlation studies among vegetative, fruit physicochemical characters of guava (Psidium guajava L.). International Journal of Agricultural Sciences, 9(26); pp.-4322-4324.

Thorp, R. W. 1996. Bee management for pollination. In W. C. Micke (Ed.), Almond Production Manual (pp. $132-$ 154): UC ANR

Westwood, M. N., Reimer, F. C. and Quackenbush, V. L. 1963. Long term yield as related to ultimate tree size of three pears varieties grown on rootstocks of five Pyrus species. Proc. American Soc. Hort. Sci. 82: 103-8.

Wright, A. H., Embree, C. G., Nichols, D.S., Prange, R. K., Harrison, P.A. and Delong, J. M. 2006. Fruit mass, colour and yield of'Honeycrisp'TM apples are influenced by manually-adjustedfruit population and tree form. Journal of Horticultural Scienceand Biotechnology81: 397-401.

Yldrm, F.A. and Kankaya, A. 2004. The spontaneous growth and lateral branch habit of new apple cultivars in nursery. International Journal of Agriculture and Biology 6, 492-494.

Yudohartono, T. and Ismail, B. 2013. Adaptability, Growth and Regeneration in Ex Situ Conservation Plots of Merbau. Jurnal Pemuliaan Tanaman Hutan, (7)3:179-96. 